Linköping Studies in Science and Technology

Dissertations, No 1589

\title{
Model Based Vehicle Level Diagnosis for Hybrid Electric Vehicles
}

Christofer Sundström

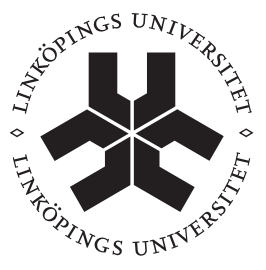

\section{Linköping University INSTITUTE OF TECHNOLOGY}

Department of Electrical Engineering

Linköping 2014 
Linköping Studies in Science and Technology

Dissertations, No 1589

Christofer Sundström

christofer.sundstrom@liu.se

ww. vehicular.isy.liu.se

Division of Vehicular Systems

Department of Electrical Engineering

Linköping University

SE-581 83 Linköping, Sweden

Copyright (C) 2014 Christofer Sundström, unless otherwise noted.

All rights reserved.

Sundström, Christofer

Model Based Vehicle Level Diagnosis for Hybrid Electric Vehicles

ISBN 978-91-7519-356-4

ISSN 0345-7524

Hybrid powertrain illustration on the cover based on illustration by Lars Eriksson.

Typeset with $\mathrm{AT}_{\mathrm{E}} \mathrm{X} 2 \varepsilon$

Printed by LiU-Tryck, Linköping, Sweden 2014 
To Tilda, Elin and Siri 



\section{ABSTRACT}

When hybridizing a vehicle, new components are added that need to be monitored due to safety and legislative demands. Diagnostic aspects due to powertrain hybridization are investigated, such as that there are more mode switches in the hybrid powertrain compared to a conventional powertrain, and that there is a freedom in choosing operating points of the components in the powertrain via the overall energy management and still fulfill the driver torque request. A model of a long haulage truck is developed, and a contribution is a new electric machine model. The machine model is of low complexity, and treats the machine constants in a different way compared to a standard model. It is shown that this model describes the power losses significantly better when adopted to real data, and that this modeling improvement leads to better signal separation between the non-faulty and faulty cases compared to the standard model.

To investigate the influence of the energy management design and sensor configuration on the diagnostic performance, two vehicle level diagnosis systems based on different sensor configurations are designed and implemented. It is found that there is a connection between the operating modes of the vehicle and the diagnostic performance, and that this interplay is of special relevance in the system based on few sensors.

In consistency based diagnosis it is investigated if there exists a solution to a set of equations with analytical redundancy, i.e. there are more equations than unknown variables. The selection of sets of equations to be included in the diagnosis system and in what order to compute the unknown variables in the used equations affect the diagnostic performance. A systematic method that finds properties and constructs residual generator candidates based on a model has been developed. Methods are also devised for utilization of the residual generators, such as initialization of dynamic residual generators, and for consideration of the fault excitation in the residuals using the internal form of the residual generators. For demonstration, the model of the hybridized truck is used in a simulation study, and it is shown that the methods significantly increase the diagnostic performance.

The models used in a diagnosis system need to be accurate for fault detection. Map based models describe the fault free behavior accurately, but fault isolability is often difficult to achieve using this kind of model. To achieve also good fault isolability performance without extensive modeling, a new diagnostic approach is presented. A map based model describes the nominal behavior, and another model, that is less accurate but in which the faults are explicitly included, is used to model how the faults affect the output signals. The approach is exemplified by designing a diagnosis system monitoring the power electronics and the electric machine in a hybrid vehicle, and simulations show that the approach works well. 



\section{POPULÄRVETENSKAPLIG SAMMANFATTNING}

Ett diagnossystem övervakar ett system för att fastställa om det är helt eller trasigt. Ett första steg är att upptäcka ett eventuellt fel, men det är även önskvärt att kunna peka ut vilken del av systemet som är trasigt. Övervakning av ett fordons drivlina är viktigt av flera anledningar, bland annat för att uppfylla lagkrav, säkerhetskrav, hög utnyttjandegrad, och effektiva reparationer. När ett fordon hybridiseras, i den här avhandlingen genom att förbränningsmotorn kombineras med en elmaskin för fordonets framdrivning, så ökar systemets komplexitet och ställer därmed stora krav på det diagnossystem som övervakar fordonet. Det är vanligt att det finns ett diagnossystem för varje komponent i fordonets drivlina, men här studeras vilka fördelar det finns med att designa ett diagnossystem som övervakar ett flertal komponenter i fordonet. En speciell egenskap hos ett hybridiserat fordon är att det finns en frihet att välja om det är elmaskinen eller förbränningsmotorn som ska användas för att driva fordonet framåt. Därför är det intressant att studera hur designen av den övergripande energistyrningen påverkar möjligheten att felövervaka fordonet.

I avhandlingen används konsistensbaserad diagnos, vilket innebär att en matematisk modell över fordonet jämförs med sensorsignaler för att fastställa fordonets felstatus. För att undersöka hur olika designval påverkar diagnosprestandan har en modell av en lastbil utvecklats och ett bidrag i avhandlingen är en ny elmaskinmodell. Det visas att den nya modellen beskriver maskinens förluster bättre än en standardmodell när dessa utvärderas på mätdata, samt att modelleringsförbättringen leder till en bättre signalseparation mellan det felfria fallet och när ett fel har uppstått i systemet. Flera olika diagnossystem har designats och implementerats i simuleringsmodellen. Simuleringar visar bland annat att det finns en koppling mellan fordonets arbetspunkter och diagnosprestandan, samt att den kopplingen är av större betydelse när få sensorer är tillgängliga.

Grunden i de utvecklade diagnossystemen är att konstruera residualgeneratorer, som här undersöker om lastbilsmodellen överensstämmer med sensormätningar. Det går att skapa tusentals residualgeneratorer baserat på en modell av ett komplext fysikaliskt system. Dessa har olika känslighet för att upptäcka fel i systemet, och därför har en metod som undersöker residualernas egenskaper baserat på en systemmodell utvecklats. Residualsignalerna i ett diagnossystem efterbehandlas och metoder för detta har konstruerats. En metod har även utvecklats för att kombinera en noggrann modell för det felfria fallet med en annan modell för samma fysikaliska system, men som beskriver hur de olika felen påverkar systemet. Detta leder till att det är möjligt att upptäcka fel i det övervakade systemet, och samtidigt även specificera vilken komponent som är felaktig, utan detaljerad modellering. För att demonstrera dessa metoder har en simuleringsstudie med lastbilsmodellen utförts där det visas att metoderna signifikant förbättrar diagnotikprestandan. 



\section{ACKNOWLEDGMENTS}

First of all I would like to express my gratitude to my supervisor Professor Lars Nielsen for letting me join his research group and for all his support during these years. My second supervisor Erik Frisk is acknowledged for the many discussions about diagnosis and good comments for improving paper manuscripts.

Daniel Eriksson and Emil Larsson are acknowledged for different discussions about diagnosis in general throughout these years. Carl Svärd is acknowledged for letting me use his implementation of the residual generator selection algorithm that is modified in Paper C, and Mattias Krysander and Per Öberg for electric machine modeling discussions. During this period I have had the pleasure to collaborate with Daniel Eriksson, Mattias Krysander, Xavier Llamas Comellas, Tomas Nilsson, Peter Nyberg, and Martin Sivertsson in different projects. Lars Eriksson is also acknowledged for involving me in an undergraduate course about vehicle propulsion in which the discussions with the students have given me many new insights about vehicle hybridization.

The industrial involvement in the project is valuable and Tobias Axelsson, Mattias Nyberg, Tobias Pettersson, Marcus Stigsson, and Nils-Gunnar Vågstedt are acknowledged for this. The colleagues at vehicular systems are acknowledged for creating a nice and pleasant atmosphere to work in. The never-ending discussions with Oskar Leufvén has given me insights in all from forestry to turbochargers, but most importantly lots of fun.

Finally, I would like to thank my family for all your support and encouragement. I would also like to express my gratitude to you Therése and to Tilda, Elin, and Siri, for bringing all your love and happiness into my life. 



\section{Contents}

1 Introduction $\quad 1$

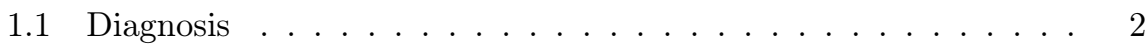

1.2 Outline and Contributions . . . . . . . . . . . . . . . . 4

1.3 Publications .................... . . 6

References ....................... 8

$\begin{array}{ll}\text { Publications } & 11\end{array}$

A Overall Monitoring and Diagnosis for Hybrid Vehicle Power$\begin{array}{ll}\text { trains } & \mathbf{1 3}\end{array}$

1 Introduction . . . . . . . . . . . . . . . . . . . 16

2 Simulation Platform . . . . . . . . . . . . . . 16

2.1 Environment . . . . . . . . . . . . . . 17

2.2 Driver model . . . . . . . . . . . . . . . . 18

2.3 Vehicle model . . . . . . . . . . . . . . . . . 18

2.4 Controller and energy management . . . . . . . . . . . 23

2.5 Driving cycles and simulation results . . . . . . . . . . 23

2.6 Sensors . . . . . . . . . . . . . . . 24

2.7 Faults . . . . . . . . . . . . . . . . . 24

3 Sensor configurations and theoretical maximum fault isolability . 27

3.1 Sensor configuration 1 . . . . . . . . . . . 27

3.2 Sensor configuration 2 . . . . . . . . . . . . . . 28

4 Diagnosis systems design . . . . . . . . . . . . . . . . . . . 28

4.1 Diagnosis system $1 \ldots \ldots$. . . . . . . . . . 30

4.2 Diagnosis system $2 \ldots \ldots . \ldots . \ldots . \ldots 32$

$5 \quad$ Results and discussion . . . . . . . . . . . . . . . 35

5.1 Diagnosis system $1 \ldots \ldots$. . . . . . . . . . . 36

5.2 Diagnosis System 2 . . . . . . . . . . . . . . . . . . . . . . . . 38

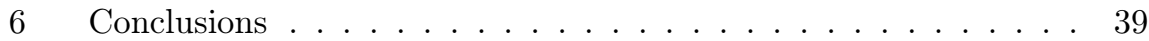

References . . . . . . . . . . . . . . . . . . 41 
B A New Electric Machine Model and its Relevance for Vehicle Level Diagnosis 43

1 Introduction . . . . . . . . . . . . . . . . 46

2 Electric machine model . . . . . . . . . . . . . . . . 46

$2.1 \quad$ Standard model . . . . . . . . . . . . . . . . . . . 47

$2.2 \quad$ New model . . . . . . . . . . . . . . . . . . . . . . 48

2.3 Parametrization of the models . . . . . . . . . . . . . 49

3 Vehicle Model . . . . . . . . . . . . . . . . . . . . . 52

$3.1 \quad$ Powertrain model . . . . . . . . . . . . . . . . . 53

3.2 Sensors . . . . . . . . . . . . . . 55

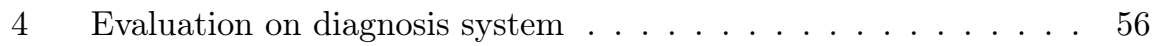

4.1 Induced fault $\ldots \ldots \ldots \ldots \ldots \ldots$

4.2 Residuals . . . . . . . . . . . . . . . . 56

$4.3 \quad$ Simulation results . . . . . . . . . . . . . . 57

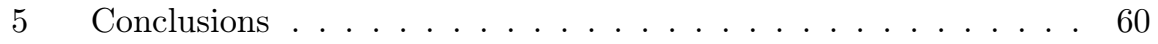

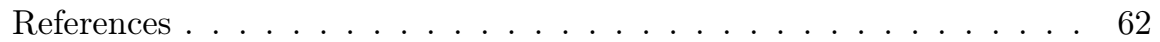

A Notation ........................ 64

C Selecting and Utilizing Sequential Residual Generators in FDI Applied to Hybrid Vehicles $\quad 67$

1 Introduction . . . . . . . . . . . . . . . . 70

2 Residual generator construction . . . . . . . . . . . . . 70

2.1 Sequential Residual Generation by Structural Analysis . . 71

2.2 An Algorithm . . . . . . . . . . . . . . . . . . 73

2.3 Dynamic Models . . . . . . . . . . . . . . . . . . 73

2.4 Modification to the Algorithm to Handle Dynamic Consistency Relations . . . . . . . . . . . . . . . . . . . . . . . 74

3 Vehicle Model . . . . . . . . . . . . . . . . . . . . 75

$3.1 \quad$ Powertrain model . . . . . . . . . . . . . . . . 75

$3.2 \quad$ Sensors . . . . . . . . . . . . . . . . . 78

3.3 Induced faults . . . . . . . . . . . . . . . 78

4 Selection of Consistency Relation . . . . . . . . . . . . . . 79

4.1 Avoiding algebraic loops by consistency relation selection 79

4.2 Properties of the sequential residual generators candidates 82

4.3 Summary and discussion . . . . . . . . . . . . . . . 83

5 Methods for Utilization of Residual Generators and Test Quantities 84

5.1 Avoid differentiating in the consistency relation using a state transformation . . . . . . . . . . . . . . 84

$5.2 \quad$ Initialization of states . . . . . . . . . . . . 86

5.3 Consider fault excitation when computing test quantities 86

$6 \quad$ Illustrative Designs and Simulation Study . . . . . . . . . . . 87

6.1 Properties of diagnosis systems used in simulation study . 88

6.2 Model used in the diagnosis system . . . . . . . . . . . 90

6.3 Initialization of states when restarting residual generators 90

6.4 Two approaches for when to update dynamic test quantities 91 
6.5 Simulations on driving cycle . . . . . . . . . . . . . . . 94

6.6 Summing up . . . . . . . . . . . . . . . . . . . . . . . . . 96

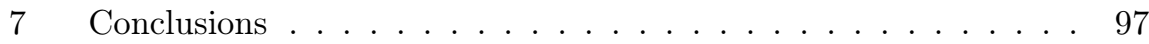

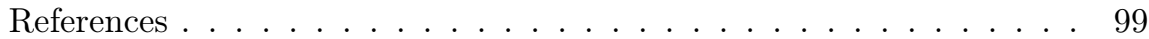

A Powertrain Model . . . . . . . . . . . . . . . . . . . . 102

B Residual generators ................... 103

B.1 Same tests in ICDS and MCDS . . . . . . . . . . . 103

B.2 ICDS ..................... . . 103

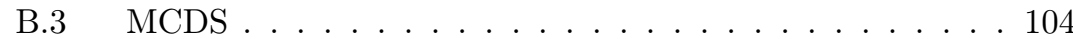

D Diagnostic Method Combining Map and Fault Models Applied on a Hybrid Electric Vehicle 105

1 Introduction . . . . . . . . . . . . . . . . . . . . 108

1.1 Contributions and outline . . . . . . . . . . . 108

2 Models of the electric machine . . . . . . . . . . . . . . . . 109

2.1 Map based model . . . . . . . . . . . . . . . . . 109

$2.2 \quad$ Analytical model . . . . . . . . . . . . . . . . . . 110

3 Combining the map and analytical models for fault modeling . . 111

$3.1 \quad$ Finding an expression for $\Delta T_{e m} \ldots \ldots$. . . . . . . 113

$3.2 \quad$ Finding an expression for $\Delta P_{\text {em }, l} \ldots \ldots \ldots$. . . . . . 114

4 Isolability gain by combining models . . . . . . . . . . . . . . . . 114

4.1 Theoretical fault isolability using map based model . . . . 114

4.2 Theoretical fault isolability using a combined model . . . 115

5 Design of a diagnosis system . . . . . . . . . . . . . . 115

5.1 State space formulation of the model . . . . . . . . . 116

5.2 Fault estimation . . . . . . . . . . . . . . 117

5.3 Design of residual generators and test quantities . . . . . 121

5.4 Summing up . . . . . . . . . . . . . . . . 127

6 Conclusions . . . . . . . . . . . . . . . . . . 128

References . . . . . . . . . . . . . . . . . 129 



\section{Chapter 1}

\section{Introduction}

There are possibilities to increase the efficiency of automotive powertrains using hybrid technology. The largest relative fuel saving can be obtained in city buses and garbage trucks with many start and stops, but also a small relative saving in the fuel consumption for long haulage trucks results in a large amount of saved fuel (Bradley, 2000). When hybridizing a vehicle, new components are added compared to a conventional vehicle, e.g. electric machines, battery pack, and power electronics (Husain, 2003; Guzzella and Sciarretta, 2013), and these components need to be accurately monitored (Diallo et al., 2013).

One reason for monitoring the powertrain is safety. Faults in the electrical components could be fatal due to the high voltage in the system. Another issue is to avoid that unintended torque is applied to the vehicle. Such faults are included in the functional safety of the vehicle, and there is an increased consideration to this field by the automotive industry. There is a global standard, ISO 26262, that provides processes and methods for the design, development, and manufacturing of vehicles, with the goal to determine the Automotive Safety Integrity Level (ASIL) in a systematic way (ISO, 2011). The ISO 26262 standard is not mandatory for heavy trucks, but this is likely to be changed by 2016 (Dardar et al., 2012).

In addition to safety, fault detection and isolation is important to decrease the vehicle ownership cost and to maximize the up-time of the vehicle. Fault detection can e.g. protect other components from breaking down if a fault occurs in a powertrain component. It is especially important to protect the battery that is expensive and may degrade fast (Chen et al., 2013), e.g. if there are large power flows in the battery. High power in the electrical components could be caused by a fault in the power electronics or the electric machine. Further, more efficient repair is possible if a fault is isolated, i.e. it is stated what component that is broken and to some extent also in what way. This leads to that the up-time of the vehicle increases, not only due to a minimization of the time 
spent at the workshop, but also due to the possibility to implement fault tolerant control strategies in the vehicle.

Monitoring the powertrain of a hybrid electric vehicle (HEV) leads to new challenges. One example of this is that there are many different operating modes in an HEV. These operating modes offer possibilities to increase the performance of the diagnosis system, since there are at least two energy converters in the powertrain and thereby there is a freedom in choosing operating points of the components via the energy management.

\subsection{Diagnosis}

A diagnosis scheme detects faults in a physical system using measurements, and there are several approaches to be used. In the process industry often data driven methods are used (Qin, 2012), while model based approaches e.g. are used in the automotive industry. Examples of model based approaches used in the control community are parity equation (Chow and Willsky, 1984), variable elimination (Staroswiecki and Comtet-Varga, 2001), parameter estimation (Isermann, 2006), state-observer (Frank, 1994), and residual generator (Blanke et al., 2006) techniques. From the AI field a common approach is consistency based diagnosis (de Kleer et al., 1992), that can be based on a general diagnostic engine (de Kleer and Williams, 1987; Struss and Dressler, 1989). An overview of the theories used in the control and AI communities is found in Travé-Massuyès (2014).

A diagnosis system using a model based approach uses a model of the monitored system, including a set of model equations $E$, describing the connection between the control and sensor signals for the nominal case. A residual generator included in the diagnosis system is designed based on a subset of the model equations, $\bar{E} \subseteq E$, with analytical redundancy, generically meaning there are more equations than unknown variables. One basic principle when constructing a residual generator based on $\bar{E}$, is that a subset $E^{\prime} \subseteq \bar{E}$ of the equations is used to compute the unknown variables in $\bar{E}$, and the other equations, i.e. $\bar{E} \backslash E^{\prime}$, are used to investigate the consistency between the model $\bar{E}$ and the observations. Often the residual generators are based on a set of equations with analytical redundancy one, i.e. there is one more equation in $\bar{E}$ than there are unknown variables in $\bar{E}$. The equations used to investigate the consistency between the model and the observations is called consistency relation or analytical redundancy relation (ARR) (Cassar and Staroswiecki, 1997; Staroswiecki and Comtet-Varga, 2001).

The computation of the unknown variables in a residual generator can be done by finding algebraic expressions for the variables or using numerical techniques, see e.g. (Brenan et al., 1996). One disadvantage using numerical solvers in nonlinear systems is that it is generally more computationally demanding compared to using algebraic expressions. Here, the designed diagnosis systems are supposed to be able to be implemented in a truck with limited computational 


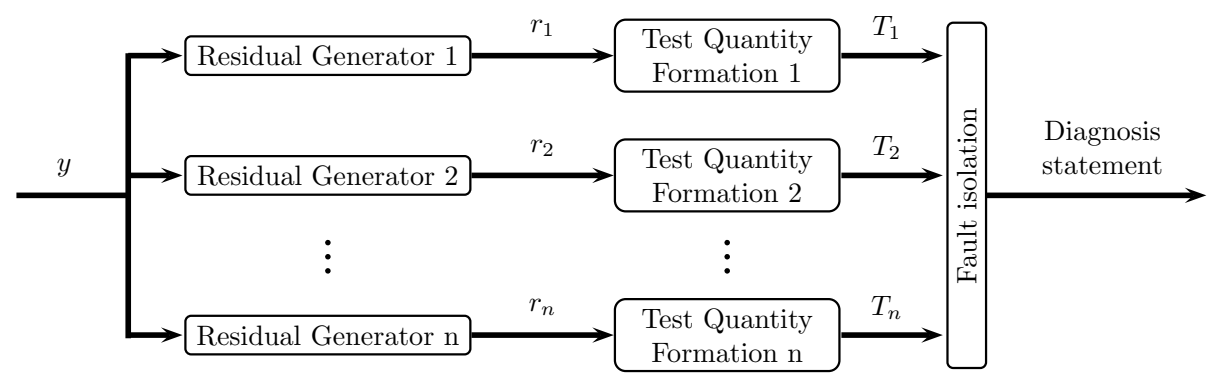

Figure 1.1: A typical diagnosis system includes several residuals that are post processed to form test quantities, and a fault isolation scheme to pinpoint which fault that has occurred.

power, and therefore algebraic expressions are found for the variables in the residual generators in Papers A-C, while the faults are estimated in stateobservers in Paper D.

A diagnosis system often consists of several residual generators that are sensitive to different faults (Blanke et al., 2006). To reduce the noise level in the residual signals, these are post processed to form test quantities, as can be seen in Figure 1.1. The diagnosis statement is computed in a fault isolation scheme, where information about what test quantities that have reacted and what faults each test quantity is expected to react to is used.

\section{STRUCTURAL ANALYSIS}

When designing a diagnosis system the well known method called structural analysis can be used (Dustegör et al., 2006; Blanke et al., 2006; Staroswiecki and Declerck, 1989). The method is based on that all variables that are used in every model equation are listed, but no information about how the variables are included (e.g. linear, exponential, differentiated) is used. Using the structural analysis method it is possible to determine what detectability and isolability of the faults that are possible to ideally achieve given a model and a set of sensors (Krysander and Frisk, 2008).

The information about which variables that are included in each equation is included in a bipartite graph. Based on this graph a Dulmage-Mendelsohn decomposition (Dulmage and Mendelsohn, 1958) gives information about what part of the model that has analytical redundancy, and thereby can be monitored. There are several efficient tools available to find subsets of the model with analytical redundancy, and some of these are discussed and compared in Armengol et al. (2009).

Sets of model equations with analytical redundancy are of special interest when designing diagnosis systems, since they are used to construct residual generators, and are denoted ARRs, possible conflicts (Pulido and Gonzalez, 
2004), and minimal structurally overdetermined (MSO) sets (Krysander et al., 2008 ) by different authors. A set of equations, $\mathcal{M}$, is structurally overdetermined if there are more equations than unknowns in $\mathcal{M}$. The set $\mathcal{M}$ is an MSO set if there is no subset of $\mathcal{M}$ that is structurally overdetermined. The structural method used when designing the diagnosis systems in Papers A-C are described in Krysander et al. (2008); Krysander and Frisk (2008).

\section{VEHICLE LEVEL DIAGNOSIS}

The manufacturers of the different components in a vehicle powertrain often also deliver a diagnosis system monitoring each component. When the components are connected in a hybrid powertrain it is however possible to design a diagnosis system monitoring the entire powertrain. This type of overall diagnosis is here called vehicle level diagnosis, and is the main emphasis of this thesis. There are several possible benefits of using such a diagnosis system. One benefit is that the performance of the diagnosis may increase, and another benefit is that it may be possible to monitor the components by using fewer sensors, compared to using separate diagnosis systems for each component in the powertrain.

\subsection{Outline And Contributions}

The aim of this work is to investigate aspects influencing diagnosis on vehicle level regarding performance, design complexity, and computational complexity. Examples of such aspects are how the design of a diagnosis system affect performance, but also the importance of using accurate models for the purpose of diagnosis. A third example of an aspect is how the sensor configuration affects the diagnosis system. The aspects mentioned above are generic when designing diagnosis systems, but an aspect that is important to understand when monitoring HEVs is how the design of the energy management in combination with the driving mission either can hide or attenuate a fault. This aspect is of higher relevance in HEVs compared to conventional vehicles, since there are more mode shifts in the hybrid system, and there is a freedom in selecting operating modes of the powertrain components via the overall energy management. The understanding of such issues is crucial when constructing a diagnosis system on vehicle level for hybrid trucks.

Diagnostic aspects are investigated in the papers included in the thesis, and a summary of the contributions in each paper is presented below.

\section{PAPER A}

A simulation platform is used to evaluate the designed diagnosis systems in Papers A-D. The platform includes a vehicle powertrain model, possibility to induce faults in the powertrain, and a diagnosis system. Most of the powertrain component models are obtained from the existing MATLAB/SIMULINK model libraries CAPSIM (Fredriksson et al., 2006) and QSS (Guzzella and Amstutz, 
1999), but are modified to represent a parallel hybrid truck as well as to include the possibility to add sensor noise and induce faults in the system. The simulation platform, with emphasis on the powertrain model, is described in Paper A and the model equations are given in the appendix of Paper $\mathrm{C}$. In addition to the model description, in Paper A also two diagnosis systems are designed and implemented in the simulation platform. The two diagnosis systems are based on two different sensor configurations to investigate different aspects affecting the diagnosis of hybrid electric vehicles, such as how the choice of the sensor configuration affects the model based diagnosis system, but also the connection between the diagnostic performance and the operating modes of the vehicle. It is found that all faults are detected in both diagnosis systems, but full fault isolability is only achieved in the system based on more sensors. Further, there is a connection between the operating modes of the vehicle and the diagnostic performance, and this interplay is of special relevance in the system based on few sensors.

Paper A is a modified version of Sundström et al. (2010) extended with work presented in Sundström (2011).

\section{PAPER B}

When comparing the electric machine model used in Paper A, that also is described in Guzzella and Sciarretta (2013), to measurement data of an electric rear axle drive, it is found that the model does not capture the characteristics of the power losses in the machine. Therefore a new model of the electric machine is presented in Paper B. The model has low complexity to be able to use the model for on-board applications, such as in a diagnosis system. The new model treats the machine constants in a different way compared to the model described in Guzzella and Sciarretta (2013), which results in a different expression for the power losses. It is shown that the new model describes the power losses significantly better when adopted to real data compared to the standard model. The significance of the modeling improvement is demonstrated using a task in vehicle diagnosis where it is shown that the separation between the non-faulty and faulty cases is better and the resulting diagnostic performance is improved.

\section{PAPER C}

There are many residual generator candidates of a physical system, and a few of these are to be selected to be used in the diagnosis system. In Paper $\mathrm{C}$ the residual generators are based on MSOs, and all but one equation is used to compute the unknown variables and one equation is used to investigate the consistency between the model and the observations. A systematic method, that is based on Svärd and Nyberg (2010), to investigate the properties of the residual generators is described in the paper. The properties may differ between different residual generators, even these based on the same set of model equations, and therefore this kind of analysis is important. It may e.g. be 
possible to find residual generators without algebraic loops, that are unique, or that either include differentiation or integration of dynamic equations. The algorithm proposed in Svärd and Nyberg (2010) is in Paper C extended to also consider the consistency relation in the analysis, and it is shown that only a small fraction of all residual generator candidates fulfill fundamental requirements, and thereby proves the value of such systematic methods. In addition, methods are devised for utilization of the residual generators, such as initialization of dynamic residual generators. A proposed method, considering the fault excitation in the residuals using the internal form of the residuals, significantly increases the diagnosis performance. The hybrid electric vehicle model is used in a simulation study for demonstration, but the methods used are general in character and provides a basis when designing diagnosis systems for other complex systems.

Paper C relies partly on work presented in Sundström et al. (2011).

\section{PAPER D}

High model accuracy directly results in good fault detection performance in a model based diagnosis system, and can be achieved by the use of a map based model. However, one drawback using such a model in a diagnosis system is the difficulty to isolate faults from each other, since internal physical phenomena are not described by the model. In Paper D a new diagnostic approach is presented to achieve also good fault isolability performance without extensive modeling. The map based model describes the nominal behavior of the monitored system, and another model, that is a less accurate but in which the faults are explicitly included, is used to model how the faults affect the output signals. The benefit of this approach is that data for a faulty system is not required, and that the accuracy demands on the model used for fault modeling are lower than for designing a diagnosis system without using the map based model. The approach is exemplified by designing an observer based diagnosis system monitoring the power electronics and the electric machine used in a hybrid electric powertrain, and simulations show that the approach works well.

Paper D relies partly on work presented in Sundström et al. (2013).

\subsection{Publications}

The research work leading to this thesis is presented in the following papers published by the author.

\section{JOURNAL PAPERS}

- C. Sundström, E. Frisk, and L. Nielsen. Selecting and utilizing sequential residual generators in FDI applied to hybrid vehicles. Systems, Man, and Cybernetics: Systems, IEEE Transactions on, 44(2):172-185, February 2014 (Paper C) 


\section{SubmitTED}

- C. Sundström, E. Frisk, and L. Nielsen. A new electric machine model and its relevance for vehicle level diagnosis. 2014a. Submitted to Journal (Paper B)

- C. Sundström, E. Frisk, and L. Nielsen. Diagnostic method combining map and fault models applied on a hybrid electric vehicle. 2014b. Submitted to Journal (Paper D)

\section{Conference Papers}

- C. Sundström, E. Frisk, and L. Nielsen. Fault monitoring of the electric machine in a hybrid vehicle. In 7th IFAC Symposium on Advances in Automotive Control, pages 548-553, Tokyo, Japan, 2013

- C. Sundström, E. Frisk, and L. Nielsen. Residual generator selection for fault diagnosis of hybrid vehicle powertrains. In IFAC World Congress, Milano, Italy, 2011

- C. Sundström, E. Frisk, and L. Nielsen. Overall monitoring and diagnosis for hybrid vehicle powertrains. In 6th IFAC Symposium on Advances in Automotive Control, pages 119-124, Munich, Germany, 2010 (Basis for Paper A) 


\section{REFERENCES}

ISO 26262. Road Vehicles - Functional Safety. International Standard, 2011.

J. Armengol, A. Bregon, T. Escobet, E. R. Gelso, M. Krysander, M. Nyberg, X. Olive, B. Pulido, and L. Trave-Massuyes. Minimal structurally overdetermined sets for residual generation: A comparison of alternative approaches. In Proceedings of IFAC Safeprocess'09, Barcelona, Spain, 2009.

M. Blanke, M. Kinnaert, J. Lunze, and M. Staroswiecki. Diagnosis and FaultTolerant Control. Springer, 2nd edition, 2006.

R. Bradley. Technology roadmap for the 21st century truck program. Technical Report 21CT-001, U.S. Department of Energy, Oak Ridge, Tennessee, December 2000 .

K. E. Brenan, S. L. Campbell, and L. R. Petzold. Numerical Solution of Initial-Value Problems in Differential-Algebraic Equations. Siam, 1996.

J. Cassar and M. Staroswiecki. A structural approach for the design of failure detection and identification systems. In Proceedings of IFAC Control of Industrial Systems, Belfort, France, 1997.

Z. Chen, Y. Fu, and C. Mi. State of charge estimation of lithium-ion batteries in electric drive vehicles using extended kalman filtering. Vehicular Technology, IEEE Transactions on, 62(3):1020-1030, 2013.

E. Chow and A. Willsky. Analytical redundancy and the design of robust failure detection systems. Automatic Control, IEEE Transactions on, 29(7): $603-614$, July 1984 .

R. Dardar, B. Gallina, A. Johnsen, K. Lundqvist, and M. Nyberg. Industrial experiences of building a safety case in compliance with ISO 26262. In IEEE 23rd International Symposium on Software Reliability Engineering Workshops (ISSREW), pages 349-354, 2012.

J. de Kleer and B. C. Williams. Diagnosing multiple faults. Artificial Intelligence, 32:97-130, April 1987.

J. de Kleer, A. Mackworth, and R. Reiter. Characterizing diagnoses and systems. Artificial Intelligence, 56(2-3):197-222, 1992.

D. Diallo, M. Benbouzid, and M. Masrur. Special section on condition monitoring and fault accommodation in electric and hybrid propulsion systems. Vehicular Technology, IEEE Transactions on, 62(3):962-964, 2013.

A. Dulmage and N. Mendelsohn. Coverings of bipartite graphs. Canadian J. of Mathematics, 10:517-534, 1958. 
D. Dustegör, E. Frisk, V. Coquempot, M. Krysander, and M. Staroswiecki. Structural analysis of fault isolability in the DAMADICS benchmark. Control Engineering Practice, 14(6):597-608, 2006.

P. M. Frank. Enhancement of robustness in observer-based fault detection. International J. of Control, 59(4):955-981, 1994.

J. Fredriksson, J. Larsson, J. Sjöberg, and P. Krus. Evaluating hybrid electric and fuel cell vehicles using the capsim simulation environment. In 22nd International Battery, Hybrid and Fuel Cell Electric Vehicle Symposium E Exposition, pages 1994 -2004, Yokohama, Japan, 2006.

L. Guzzella and A. Amstutz. CAE tools for quasi-static modeling and optimization of hybrid powertrains. IEEE Trans. on Vehicular Technology, 48(6): $1762-1769$, November 1999.

L. Guzzella and A. Sciarretta. Vehicle Propulsion System, Introduction to Modeling and Optimization. Springer Verlag, Zürich, 3 edition, 2013.

I. Husain. Electric and Hybrid Vehicles. CRC Press LLC, 2003.

R. Isermann. Fault Diagnosis Systems - An Introduction from fault Detection to Fault Tolerance. Springer Verlag, 2006.

M. Krysander and E. Frisk. Sensor placement for fault diagnosis. IEEE Trans. on SMC-Part A, 38(6):1398-1410, 2008.

M. Krysander, J. Åslund, and M. Nyberg. An efficient algorithm for finding minimal over-constrained sub-systems for model-based diagnosis. IEEE Trans. on $S M C$ - Part A, 38(1), 2008.

B. Pulido and C. Gonzalez. Possible conflicts: a compilation technique for consistency-based diagnosis. IEEE Trans. on SMC - Part B, 34(5):2192 -2206, October 2004.

S. J. Qin. Survey on data-driven industrial process monitoring and diagnosis. Annual Reviews in Control, 36(2):220 - 234, 2012. ISSN 1367-5788.

M. Staroswiecki and G. Comtet-Varga. Analytical redundancy relations for fault detection and isolation in algebraic dynamic systems. Automatica, 37(5): $687-699,2001$.

M. Staroswiecki and P. Declerck. Analytical redundancy in non-linear interconnected systems by means of structural analysis. In Proceedings of IFAC AIPAC'89, pages 51-55, Nancy, France, 1989.

P. Struss and O. Dressler. "physical negation": integrating fault models into the general diagnostic engine. In Proceedings of the 11th international joint conference on Artificial intelligence - Volume 2, pages 1318-1323, San Francisco, CA, 1989. 
C. Sundström. Vehicle level diagnosis for hybrid powertrains. Technical report, 2011. Licentiate thesis LiU-TEK-LIC-2011:27, Thesis No. 1488.

C. Sundström, E. Frisk, and L. Nielsen. Overall monitoring and diagnosis for hybrid vehicle powertrains. In 6th IFAC Symposium on Advances in Automotive Control, pages 119-124, Munich, Germany, 2010.

C. Sundström, E. Frisk, and L. Nielsen. Residual generator selection for fault diagnosis of hybrid vehicle powertrains. In IFAC World Congress, Milano, Italy, 2011.

C. Sundström, E. Frisk, and L. Nielsen. Fault monitoring of the electric machine in a hybrid vehicle. In rth IFAC Symposium on Advances in Automotive Control, pages 548-553, Tokyo, Japan, 2013.

C. Sundström, E. Frisk, and L. Nielsen. Selecting and utilizing sequential residual generators in FDI applied to hybrid vehicles. Systems, Man, and Cybernetics: Systems, IEEE Transactions on, 44(2):172-185, February 2014.

C. Sundström, E. Frisk, and L. Nielsen. A new electric machine model and its relevance for vehicle level diagnosis. 2014a. Submitted to Journal.

C. Sundström, E. Frisk, and L. Nielsen. Diagnostic method combining map and fault models applied on a hybrid electric vehicle. 2014b. Submitted to Journal.

C. Svärd and M. Nyberg. Residual generators for fault diagnosis using computation sequences with mixed causality applied to automotive systems. IEEE Trans. on SMC - Part A, 40(6):1310-1328, 2010.

L. Travé-Massuyès. Bridging control and artificial intelligence theories for diagnosis: A survey. Engineering Applications of Artificial Intelligence, 27(0):1 $-16,2014$. 
Publications 



\section{Papers}

The articles associated with this thesis have been removed for copyright reasons. For more details about these see:

http://urn.kb.se/resolve?urn=urn:nbn:se:liu:diva-105487 
Linköping studies in science and technology, Dissertations

Division of Vehicular Systems

Department of Electrical Engineering

Linköping University

No 1 Magnus Pettersson, Driveline Modeling and Control, 1997.

No 2 Lars Eriksson, Spark Advance Modeling and Control, 1999.

No 3 Mattias Nyberg, Model Based Fault Diagnosis: Methods, Theory, and Automotive Engine Applications, 1999.

No 4 Erik Frisk, Residual Generation for Fault Diagnosis, 2001.

No 5 Per Andersson, Air Charge Estimation in Turbocharged Spark Ignition Engines, 2005.

No 6 Mattias Krysander, Design and Analysis of Diagnosis Systems Using Structural Methods, 2006.

No 7 Jonas Biteus, Fault Isolation in Distributed Embedded Systems, 2007.

No 8 Ylva Nilsson, Modelling for Fuel Optimal Control of a Variable Compression Engine, 2007.

No 9 Markus Klein, Single-Zone Cylinder Pressure Modeling and Estimation for Heat Release Analysis of SI Engines, 2007.

No 10 Anders Fröberg, Efficient Simulation and Optimal Control for Vehicle Propulsion, 2008.

No 11 Per Öberg, A DAE Formulation for Multi-Zone Thermodynamic Models and its Application to CVCP Engines, 2009.

No 12 Johan Wahlström, Control of EGR and VGT for Emission Control and Pumping Work Minimization in Diesel Engines, 2009.

No 13 Anna Pernestål, Probabilistic Fault Diagnosis with Automotive Applications, 2009.

No 14 Erik Hellström, Look-ahead Control of Heavy Vehicles, 2010.

No 15 Erik Höckerdal, Model Error Compensation in ODE and DAE Estimators with Automotive Engine Applications, 2011. 
No 16 Carl Svärd, Methods for Automated Design of Fault Detection and Isolation Systems with Automotive Applications, 2012.

No 17 Oskar Leufvén, Modeling for control of centrifugal compressors, 2013. 